\title{
Strategi Kepala Sekolah Dalam Mempertahankan Mutu Pendidikan Pada Masa Pandemi Covid-19 di SMA Ar-Rahmah Malang
}

\author{
${ }^{* 1}$ Burhana Rizky P., ${ }^{2}$ Rodiyatin Puput T., ${ }^{3}$ Iffah Afidah \\ ${ }^{123}$ Magister Manajemen Pendidikan Islam, Universitas Maulana Malik Ibrahim Malang \\ Email: ${ }^{1}$ brizkyp@gmail.com
}

Tanggal Submitt: 04/04/2021 Tanggal diterima: 06/04/2021 Tanggal Terbit: 13/07/2021

\begin{abstract}
Scholl is one of the aspects affected by the Covid-19 pandemic, therefore the importance of the strategy of educational institution leaders in maintaining the quality of their education so that they can always maintain their existance to the wider community, therefore this study has the aim to knowing the strategies applied by the head master of SMA Ar-Rahmah in maintaining the wuality of education during the Covid-19 pandemic. The methode used in this research is kualitative descriptive explanatory, information retrieval using structured interview with the principal as a resource. The information analysis that is tried in problem research is reduction, presentation, and the drawing of conclusions. The result found in this study are as follow: 1) the headmaster maintains the quality of this education by improving teacher professionalism by providing coaching and training such as saqofiyah coaching which aims to maintain the faith of teachers to carry out learning well, 2) during this pandemic the headmaster pas attention to the immunity of school residents by giving eclia test, using strict health protocols, both when the teacher enters the school environment and in the learning process, 3) the headmaster keeps the teaching and learning process going well by maintaining the health of students by providing additional foot to increase the immunity of participants students, besides providing additional activities to reduce the boredom of students in the teaching and learning process.
\end{abstract}

Keywords: Strategy Headmaster, Quality of Education

\section{Pendahuluan}

Dua belas bulan lebih sejak datangnya pandemi Coronavirus 2019 (COVID-19) di Indonesia yang mengakibatkan seluruh sektor kehidupan dituntut untuk berubah dalam kurun waktu yang singkat. Salah satu faktor yang berdampak dalam pandemi ini adalah sektor pendidikan. Banyak Negara yang mengambil kebijakan untuk melakukan pemberhentian kegiatan sekolah sebagai langkah untuk mengantisipasi penyebaran virus ini. Tak terkecuali Indonesia mengeluarkan kebijakan terkait belajar dari rumah, mengajar dari rumah, bekerja dari rumah. Semua aktivitas pendidikan dan kependidikan dikerjakan dari rumah, sehingga secara otomatis penggunaan media baik media belajar, mengajar, bekerja yang semua serba offline menjadi online. Pandemi ini memberikan dampak yang besar bagi guru dan murid, berdasarkan data UNESCO secara global terdapat 1,6 miliar murid terpaksa belajar dari rumah dan 63 juta guru terpaksa mengajar dari rumah. ${ }^{1}$

Belajar, bekerja, dan mengajar dari rumah ditetapkan melalui kebijakan Kemendikbud SE No. 4 Tahun 2020 tentang pelaksanaan kebijakan pendidikan dalam masa darurat penyebaran Coronavirus 2019. Pertimbangan dikeluarkannya kebijakan tersebut dikarenakan meningkatnya penyebaran virus sehingga kesehatan lahir dan batin siswa, guru, kepala sekolah, dan seluruh warga sekolah menjadi prioritas dalam kebijakan

${ }^{1}$ Medcom.id, 08 Oktober 2020 
pendidikan. ${ }^{2}$ Kebijakan ini merupkan langkah antisipatif pemerintah dalam meminimalisir penyebaran Covid 19, dimana interaksi antara guru dengan murid atau guru dengan guru tidak harus bertemu secara langsung, tidak harus bersentuhan atau bertatap muka. ${ }^{3}$

Pembelajaran merupakan inti dari proses pendidikan, dengan adanya perubahan kegiatan pembelajaran yang semua tatap muka menjadi pembelajaran jarak jauh atau sistem dalam jaringan (daring), memerlukan kepemimpinan kepala sekolah yang efektif untuk merancang pembelajaran jarak jauh yang efektif agar mutu pendidikan tetap terjamin. Oleh sebab itu kepala sekolah membutuhkan keahlian leadership yang baik dengan memahami kompetensi kepala sekolah. Dengan adanya pandemi Covis 19 ini kepala madrasah memiliki tantangan baru untuk senantiasa mempunyai strategi agar dapat melayani konsumen pendidikan dengan baik. ${ }^{4}$ Salah satu strategi yang dapat diterapkan lembaga pendidikan dalam menjaga dan meningkatkan daya saing sekolah melalui strategi bersaing.

Upaya mencari posisi bersaing yang menguntungkan dalam suatu arena fundamental dimana persaingan berlangsung. Dalam hal ini lembaga pendidikan perlu merumuskan strategi podidi yang tepat dalam memenangkan persaingan. Tujuan dari strategi ini untuk membina lembaga pendidikan agar mampu melindungi diri sendiri dengan sebaik-baiknya dari tekanan persaingan sehingga dapat mempengaruhi tekanan tersebut secara positif. Sehingga menciptakan posisi bertahan yang aman (defendable position) diperlukan adanya strategi bersaing yang efektif baik tindakan menyterang (ofensif) maupun bertahan (defensive). ${ }^{5}$ Tantangan tersebut menguji kepala sekolah sejauhmana kesanggupan untuk melakukan strategi kepemimpinan ditengah pandemi ini. Strategi kepemimpinanlah yang menjadi kunci kesuksesan suatu organisasi untuk mencapai tujuan pendidikan. ${ }^{6}$

Kepemimpinan adalah terjemahan dari kata "leadership" yang berasal dari kata leader. Pemimpin (leader) ialah orang yang memipimin, sedangkan pimpinan merupakan jabatannya. Secara etimologi, istilah kepemimpinan berasal dari kata "pimpin" yang artinya bombing atau tuntun. Dari kata pimpin tersebut maka lahirlah kata kerja "memimpin" yang artinya membimbing dan menuntun ${ }^{7}$

Kepala sekolah yang efektif diperlukan sebagai sosok yang mampu mempengaruhi dan menggerakkan bawahannya untuk mencapai tujuan pendidikan sekolah. ${ }^{8}$ Kepemimpinan itu sendiri merupakan suatu kemampuan dan kesiapan kepala sekolah dalam mempengaruhi, membimbing, serta menggerakkan staf sekolah agar

\footnotetext{
2 Kemendikbud SE No 4 Tahun 2020

3 Ahmad Muzawir Saleh, "Problematika Kebijakan Pendidikan Di Tengah Pandemi Dan Dampaknya Terhadap Proses Pembelajaran Di Indonesia" (n.d.).

4 M. Abdullah, "Manajemen Mutu Pendidikan Sekolah," Jurnal Penelitian Pendidikan 17, no. 03 (n.d.): 190.

5 Porter, Strategi Bersaing (Competitive Strategy): Teknik. Menganalisis Industri Dan Pesaing (Tangerang: Karisma Pyblishing Group, 2007).

${ }^{6}$ Stephen J. Bagnato, Intervention, Authentics Assessment For Early Childhood (New York, 2007). 2012) hal. 4

${ }^{7}$ Imam Machali, Kepemimpinan Pendidiakn dan Pembangunan Karakter, (Yogyakarta: Pedagogia, 2011).

${ }^{8}$ Nur Zazin, Gerakan Menata Mutu Pendidikan: Teori Dan Aplikasi (Yogyakarta: Ar-Ruzz Media,
} 
bekerja secara efektif dalam mencapai tujuan pendidikan yang telah ditetapkan oleh lembaga pendidikan. Hadawi Nawawi, berpendapat bahwa kepemimpinan adalah kemampuan menggerakkan, memberikan motivasi dan mempengaruhi orang-orang agar bersedia melakukan tindakan-tindakan yang terarah pada pencapaian tujuan melalui keberanian mengambil keputsan tentang kegiatan yang dilakukan'

Suharsimi Arikunto, kepemimpinan adalah usaha yang dilakukan untuk mempengaruhi anggota kelompok agar mereka dengan suka rela menyumbangkan kemampuannya secara maksimal demi pencapaian tujuan kelompok yang telah ditetapkan. ${ }^{10}$ Kepemimpinan merupakan cara seorang pemimpin dalam mempengaruhi perilaku bawahannya agar mau bekerjasama secara produktif untuk mencapai tujuan organisasi. Strategi merupakan seni dan pengetahuan dalam merencanakan, menerapkan serta mengevaluasi keputusan lintas fungsional untuk mencapai tujuan organisasi. ${ }^{11}$ Seorang pemimpin dalam menerapkan strategi harus menganalisis menggunakan analisis SWOT, sehingga mengetahui posisi lembaga pendidikan dan strategi yang digunakan bisa tepat pada sasan pendidikan sehingga dapat mempertahankan mutu pendidikan tersebut. Dengan adanya strategi kepemimpinan maka lembaga pendidikan akan mendapatkan posisi yang kuat dalam lingkungannya dikarenakan lembaga pendidikan mengedepankan pemenuhan kebutuhan dan permintaan pelanggan. ${ }^{12}$

Berdasarkan definisi diatas maka penulis memberikan pandangan bahwa aktivitas kepemimpinan merupakanupaya secara kolektif (bersama) dalam berfikir, bertindak dan memecahkan masalah yang dihadapi oleh lembaga secara bersama-sama agar tujuan yang direncanakan dapat direalisasikan dengan baik.

Mutu berasal dari kata lain qualitas (property, mutu, nilai, karakteristik, fitur, kemampuan). Dalam dunia yang sangat kompetitif dengan meningkatnya permintaan konsumen, mutu telah menjadi factor kunci untuk bertahan hidup di pasar, profitabilitas dan pengembangan, tidak hanya untuk sector dan organisasi individual, tetapi juga untuk perekonomian seluruh Negara. Hanya sedikit perusahaan di Indonesia yang mengakui mutu pendidikan sebagai factor kunci untuk meningkatkan mutu bisnis, dan oleh karena itu untuk memperkuat keunggulan produktif ${ }^{13}$.

Mutu pendidikan adalah konsep, dinamis multi-dinamis yang tidak hanya mengacu pada model pendidikan, tetapi juga untuk misi kelembagaan dan sasarannya, serta standar spesifik dari sistem, fasilitas, program atau acara. Teori dan praktik pedagogis telah mencoba untuk menentukan mutu pendidikan. Dalam pendidikan, hanya mungkin untuk menentukan mutu dengan membandingkan hasil dengan sasaran yang diberikan, atau dengan membandingkannya dengan standar yang ditetapkan sebelumnya ${ }^{14}$.

\footnotetext{
${ }^{9}$ Hadari Nawawi, Administrasi Pendidikan, (Jakarta: Haji Masagung, 1998), hlm 81

${ }_{10}$ Suharsimi Arikunto, Organisasi dan Administrasi Pendidikan Teknologi dan Kejuruan, Jakarta: Rajawali Pers, 1990) Hal. 183

${ }^{11}$ Fred R. David, Manajemen Strategi (Jakarta: Salemba Empat, 2009).

12 C. Markides, "What Is Strategy And How Do You Know If You Have One?," Bussines Strategy Review Summer 15, no. 2 (n.d.): 5-12.

13 Sudarwan Danim, Visi Baru Manajemen Sekolah; dari Unit Birokrasi ke Lembaga Akademi (Jakarta: Bumi Aksara, 2008), 53.

${ }^{14}$ Nanang Fattah, Landasan Manajemen Pendidikan (Bandung: Remaja Rosda Karya, 2010), 19
} 
Penelitian Sholehan menyatakan kepemimpinan kyai merupakan salah satu faktor yang menentukan mutu suatu pendidikan. ${ }^{15}$ Budi menjelaskan bahwa terdapat pengaruh signifikan antara kepemimpina kepala seklah terdahap mutu pendidikan. ${ }^{16}$ Dalam Oding mengemukakan bahwa kepemimpinan kepala sekolah yang memiliki kualitas layanana yang baik memiliki pengaruh signifikan terhadap mutu pendidikan. ${ }^{17}$ Sedangkan dalam penelitian Suhendar, dkk menjelaskan bahwa kepemimpinan kyai tidak berpengaruh secara signifikan terhadap mutu pendidikan di pesantren dikarenakan tiga alasan, secara teoritis, empiris, dan metodologis. ${ }^{18}$

Sudrajat, dkk, dalam penelitiannya mengemukakan bahwa peranan kepala sekolah sangatlah penting dalam proses kegiatan pendidikan. Pada masa pandemi covid 19 kepala sekolah harus memiliki langkah strategis agar sekolah mampu menciptakan rasa aman, kepuasan, dan tetap menjalankan program sekolah serta berusaha meningkatkan kualitas lembaga pendidikannya. ${ }^{19}$ SMA Ar-Rahmah Putra sebuah lembaga pendidikan formal yang bernuansa Islami yang dibawah naungan pondok pesantren hidayatullah Malang yang memiliki program unggulan bilingual, tahfidz, dan Islamic character school. Seluruh peserta didik diwajibkan untuk bermukim di pondok pesantren hidayatullah Malang.

\section{Metode Penelitian}

Dalam pemaparan penelitian ini memakai metode deskriptif eksploratif, Arikunto membagikan statement kalau "metode deskriptif eksploratif selaku sesuatu studi biasanya digunakan untuk membuat mendeskripsikan sesuatu fenomena ataupun objek yang terdapat. ${ }^{20}$ Tudak hanya itu, merujuk kepada variabel serta rentang waktu yang digunakan dalam riset ini, Arikunto pula membagikan merminan kalau "riset yang dicoba dengan menarangkan ataupun menggambarkan variabel masa kemudian serta saat ini merupakan riset deskriptif. ${ }^{21}$ Dari definisi tersebut, dapat diketahui bahwa sekup wilayah dari penelitian ini terbatas, dalam arti penelitian deskriptif ini hanya meneliti informasi dari informan wawancara dalam kuantitas yang sempit yaitu kepala sekolah Bapak FahmiAhmad Supardi, M.M.

Tata cara pengumpulan data dalam studi ini mengenakan wawancara dengan kepala sekolah. Metode pengambilan informasi memakai wawancara terstruktur kepada

15 Solehan, "Strategi Peningkatan Mutu Pendidikan Di Madrasah Aliah Negeri Muara Enim," Raden Fattah 14 (2014): 1-15.

16 Budi Susanto, "The Influence Of Headmaster Leadership, School Climate And Teacher Competence Toward Education Quality In Mts Jeneponto Regency” 1, no. 2 (2018): 23-39.

17 Oding Supriadi, "Pengaruh Gaya Kepemimpinan Dan Kualitas Layanan Terhadap Mutu Pendidikan Di Kabupaten Pandeglang Provinsi Banten," Tabularasa PPS UNIMED 6, no. 2 (2009): 98111.

${ }^{18}$ Ismet Basuki. Suhendar, Soedjarwo, “Analisis Pengaruh Kepemimpinan Kyai, Budaya Pesantren, Dan Motivasi Kerja Guru Terhadap Mutu Pendidikan Pesantren Di Provinsi Banten” 34 (2017): 161-172.

${ }^{19}$ Cucu Jajat Sudrajat et al., "Jurnal Obsesi : Jurnal Pendidikan Anak Usia Dini Strategi Kepala TK Dalam Meningkatkan Mutu Pendidikan Pada Masa Pandemi Covid 19 Abstrak” 5, no. 1 (2021): 508-520.

${ }^{20}$ Suharsimi Arikunto. Prosedur Penelitian: Suatu Pendekatan Praktek. Jakarta: PT. Rineka Cipta (1998): 247

${ }^{21}$ Ibid, : 10 
kepala sekolah sebagai nara sumber. ${ }^{22}$ Wawancara terstruktur ialah wawancara yang dicoba oleh pewawancara dengan metode mengadakan tanya jawab langsung serta berpedoman pada sederetan persoalan yang telah disusun tadinya. ${ }^{23}$ Analisis informasi yang dicoba pada riset riset permasalahan ialah dengan memakai analisis 3 jalan. Ada 3 jalan analisis informasi kualitatif, ialah reduksi informasi, penyajian informasi, serta penarikan kesimpulan. ${ }^{24}$

\section{Pembahasan}

SMA Ar-Rahmah merupakan lembaga pendidikan dibawah naungan Yayasan Pondok Modern Hidayatullah Malang. Lembaga pendidikan dibawah naungan pondok modern dimana seluruh peserta didik diwajibkan untuk tinggal di pondok tersebut. Pada masa pandemi covid-19 ini, kepala sekolah sebagai pimpinan pada satuan pendidikan memiliki peranan yang besar dalam mempertahankan mutu pendidikan. Demikian di SMA Ar-Rahmah juga memiliki tugas pokok dan fungsi yang penting dalam mempertahankan mutu pendidikan pada masa pandemi ini.

Pada awal ketika datangnya pandemi covid-19 kepala sekolah menerapkan kebijakan terkait pembelajaran jarak jauh atau biasa disebut dengan daring (dalam jaringan) dan para peserta didik dipulangkan kerumah masing-masing. Pembelajaran jarak jauh ini hanya berlangsung selama 3 minggi dengan berbagai pertimbangan, salah satunya kurang efektifnya pembelajaran daring sehingga setelah 3 minggu tersebut kepala sekolah membuat kebijakan baru bahwa pembelajaran mulai kembali seperti biasanya atau luring (luar jaringan).

Adapun strategi kepala sekolah dalam mempertahankan mutu lembaga pendidikan sebagai berikut, Pertama, meningkatkan profesionalisme guru dengan memberikan pembinaan saqofiyah untuk menjaga iman para guru agar melaksanakan pembelajaran dengan baik. Seperti yang dikemukakan oleh Makawimbang, bahwa guru yang profesional adalah guru yang memiliki pengalaman mengajar, kapasitas intelektual, moral, iman, takwa, tanggung jawab, dan wawasan kependidikan yang luas serta memiliki keterbukaan profesional dalam memahami potensi, karakteristik, dan masalah peserta didik serta memiliki kemampuan untuk mengambangkan kurikulum yang ada. ${ }^{25}$ Sesuai dengan hasil penelitia Ali dan Hasanah bahwa dalam menjamin mutu pendidikan dilakukan pelatihan peningkatan kinerja guru dan penilaian kinerja guru secara online dimana sekolah tersebut menerapkan sistem pembelajaran jarak jauh pada masa pandemi Covid-19. ${ }^{26}$

${ }^{22}$ Moh Ibnul Maarif et al., "Strategi Perencanaan Manajemen Sumber Daya Manusia Di Hotel the Patra Resort and Villas Bali Kabupaten Badung Bali," Kepariwisataan Dan Hospitalitas 3, no. 1 (2019): 211225.

23 Sahid Ali and Enung Hasanah, "Kepemimpinan Kepala Sekolah Dalam Mempertahankan Mutu Pendidikan Pada Masa Pandemi Covid-19 Di SMA Muhammadiyah 3 Yogyakarta” 7, no. 1 (2021): 264272.

${ }^{24}$ Ali Sadikin and Afreni Hamidah, "Pembelajaran Daring Di Tengah Wabah Covid-19," Biodik 6, no. 2 (2020): 109-119.

25 J. H. Makawimbang, Supervisi Dan Peningkatan Mutu Pendidikan (Bandung: Alfabeta, 2011).

${ }_{26}$ Ali and Hasanah, "Kepemimpinan Kepala Sekolah Dalam Menjamin Mutu Pendidikan Pada Masa Pandemi Covid-19 Di SMA Muhammadiyah 3 Yogyakarta." 
Kedua, kepala sekolah tetap menjaga pshycal distancing baik sesama guru maupun peserta didik, selain itu kepala sekolah menerapkan prokes (prosedur kesehatan) yang ketat baik ketika guru masuk ke lingkungan sekolah maupun proses pembelajaran. Ketika masuk kelingkungan sekolah seluruh tenaga pendidik maupun kependidikan diwajibkan untuk cuci tangan, menggunakan handsanitizer, menggunakan masker, cek suhu. Selain itu seluruh tenaga pendidik dan kependidikan juga mendapatkan fasilitas tes swab antigen melalui tes Eclia ini merupakan singkatan dari Electro-Chemiluminescence Immumoassay (ECLIA) Anti-SARS-CoV-2 merupakan pemeriksaan laboratorium imunoserologi pada alat otomatik untuk mendeteksi antibodi terhadap SARS-Cov-2. Kegiatan ini merupakan salah satu bentuk ikhtiar untuk mengamankan lembaga pendidikan dari wabah, dan memastikan setiap sumber daya manusia yang ada pada sekolah ini tidak terjangkit virus covis-19. Oleh karena itu kepala madrasah memberikan pembinaan, pemahaman, serta pengontrolan. Melalui perhatian kepala sekolah terhadap guru diharapkan dapat melakukan proses pembelajaran dengan baik.

ketiga, kepala sekolah mempertahankan mutu peserta didik dengan tetap menerapkan proses pembelajaran seperti biasanya akan tetapi tetap menggunakan prokes yang sudah ditetapkan. Dengan adanya pandemi ini peserta didik hampir selama satu semester tidak ada liburan sehingga pembelajaran di sekolah dilakukan terus menerus, akan tetapi ketika waktu tertentu kepala sekolah memberikan kegiatan outbond, market day, aksi santri dan lain-lain supaya peserta didik tidak mengalami kejenuhan dalam proses belajar. Selain itu kepala sekolah juga melakukan pelatihan bakat dan minat dengan mendatangkan seorang ahli dalam bidangnya misalnya, melukis, fotografi, seni, dan lain-lain. Selain itu kesehatan peserta didik juga diperhatikan seperti penambahan vitamin, buah, madu, susu, dan lain-lain untuk meningkatkan imunitas peserta didik pada masa seperti ini.

Kepala sekolah memiliki peran kuat dalam mengkoordinasikan, menggerakan dan menyerasikan semua sumber daya yang tersedia. Kepemimpinan kepala sekolah merupakan factor utama dalam mewujudkan visi, misi, tujuan, dan sasaran sekolah. Oleh karena itu kepala sekolah dikatakan berkualitas apabila kepala sekolah dapat memberi pengaruh yang lebih baik dalam tindakan-tindakan kinerjanya. Sehingga warga sekolah dapat bekerja maksimal sesuai dengan program yang telah ditentukan. Guru dan karyawan lainnya, akan termotivasi melakukan perbaikan-perbaikan dalam kinerjanya, karena kinerja para anggota organisasi sekolah lahir dari keterampilan dan kepemimpinan kepala sekolah ${ }^{27}$

Jaminan mutu yang diterapkan oleh kepala sekolah dapat membuahkan hasil yang positif kepada para peserta didik, dengan peningkatan prestasi-prestasi yang dicapai oleh peserta didik, pada masa pandemi ini SMA Ar-Rahmah menjadi juara umum pada olimpiade pahlawan sains Indonesia (OPSI) 2020 dengan memborong 8 medali pada tingkat Nasional. Selain itu SMA Ar-Rahmah juga meraih medali emas dalam olimpiade biologi Nasional (OBN) 2021.

Pada masa pandemi ini tingkat kelulusan SNMPTN peserta didik mengalami kenaikan 35\% dari tahun sebelumnya. Hal ini dikarenakan pada masa pandemi ini

${ }^{27}$ Jerome S.Arcaro, Pendidikan Berbasis Mutu (Jogjakarta:Pustaka Pelajar, 2006).66 
peserta didik lebih fokus dalam pembelajaran sehingga prestasi dan capaian lembaga pendidikan dapat meningkat dari tahun-tahun sebelumnya. Sesuai apa yang dijelaskan oleh Usman "Output dinyatakan bermutu apabila hasil belajar akademik dan nonakademik siswa tinggi. Outcome dinyatakan bermutu apabila lulusan cepat terserap di dunia kerja, gaji wajar, semua pihak mengakui kehebatannya lulusannya dengan merasa puas" 28

Keberhasilan aplikasi manajemen kualitas terpadu di sekolah diukur dari kepuasan pelanggan baik internal maupun eksternal. Sekolah dikatakan sukses bila sanggup membagikan layanan cocok harapan pelanggan. Dengan kata lain, keberhasilan sekolah ataupun madrasah dikemukakan dalam panduan manajemen sekolah selaku berikut: 1) Siswa puas dengan layanan sekolah, 2) Orang tua siswa puas dengan layanan terhadap anaknya, 3) Pihak pemakai ataupun penerima lulusan puas sebab menerima lulusan dengan mutu besar serta cocok harapan, 4) Guru serta karyawan puas dengan layanan sekolah $^{29}$.

Dengan demikian bahwa strategi kepemimpinan kepala sekolah dalam meningkatkan mutu pendidikan pada masa pandemic covid-19, merupakan upaya yang sistematis oleh kepala sekolah yang dibantu para wakil kepala sekolah SMA Ar-Rahmah dalam menjalankan kepemimpinannya di masa pandemic ini. Hal ini untuk menjaga kualitas yang telah dicapai dan berupaya meningkatkan mutu pendidikan agar lebih baik di masa mendatang, strategi yang sudah dilaksanakan oleh kepala sekolah diatas lebih difokuskan kepada peningkatan prestasi anak-anak. SMA Ar-Rahmah harus mengutamakan kepuasan pelanggan diatas dengan perilaku kepemimpinan kepala sekolah yang mampu diteladani, bertanggung jawab, memiliki prinsip melayani bukan ingin dilayani,mampu berkolaborasidengan semua pihak, dan mampu menciptakan perubahan-perubahan. Disamping itu kepala sekolah SMA-Ar Rahmah adalah kepala sekolah yang melaksanakan program dengan pendekatan proses, sistem, mampu mengambil keputusan berdasarkan data dan fakta, mampu menjalin kerjasama dengan pihak luar dalam upaya peningkatan mutu serta senantiasa melakukan perbaikan perbaikan secara berkelanjutan. Dengan strategi itu semua maka peningkatan mutu di SMA Ar-Rahmah akan semakin baik.

\section{Catatan Akhir}

Strategi yang diterapkan oleh kepala sekolah SMA Ar-Rahmah dalam mempertahankan mutu Pendidikan pada masa pandemi ini yakni tetap menjaga profesionalitas guru dengan melakukan pembinaan-pembinaan agar tetap melaksanakan tugas pokok serta fungsinya dengan baik, pada masa pandemi seperti saat ini kepala sekolah menerapkan protokol kesehatan secara ketat untuk seluruh warga sekola, selain itu tenaga pendidik serta kependidikan juga diberikan fasilitas tes kesehatan yang bertujuan untuk mendeteksi virus corona sedini mungkin

SMA Ar-Rahmah merupakan lembaga dibawah naungan pondok modern dimana seluruh peserta didik diwajibkan untuk tinggal didalam pondok yang telah disediakan

${ }^{28}$ Husaini Usman, Manajemen: Teori,Praktik, dan riset pendidikan (Jogjakarta: Bumi Aksara, 2015). 410

${ }^{29}$ Faisal Mubarak, "Faktor Dan Indikator Mutu Pendidikan Islam," Management of Education 1, no. 1 (2004): 10-18. 
sehingga pada pandemi ini kepala sekolah memberikan makanan penunjang untuk menjaga imunitas peserta didik seperti madu, susu, ramuan, dan lain-lain. Selain itu peserta didik diberikan kegiatan-kegiatan diluar kegiatan belajar mengajar yang ditujukan agar peserta didik tidak bosan dikarenakan tidak diizinkan keluar area sekolah, seperti outbond, aksi santri, market day dan diadakan pula pengembangan bakat peserta didik.

Pada masa pandemi seperti saat ini fokus kepala sekolah adalah bagaimana kegiatan belajar mengajar bisa berjalan efektif dan efisien. Hal tersebut terbukti bahwa pada masa pandemi ini prestasi peserta didik meningkat daripada tahun sebelumnya, selain itu tinggat kelulusan untuk melanjutkan ke perguruan tinggi negeri dengan jalur undangan naik sebesar 35\% dari tahun sebelumnya. Dapat diambil kesimpulan bahwa kepala sekolah berhasil mempertahankan mutu pendidikannya dengan melihat meningkatkan prestasi peserta didik serta diakuinya output pendidikan dengan peningkatan presentase peserta didik yang diterima di perguruan tinggi negeri dengan jalur undangan.

\section{Daftar Rujukan}

Ali, Sahid, and Enung Hasanah. "Kepemimpinan Kepala Sekolah Dalam Menjamin Mutu Pendidikan Pada Masa Pandemi Covid-19 Di SMA Muhammadiyah 3 Yogyakarta" 7, no. 1 (2021): 264-272.

C. Markides. "What Is Strategy And How Do You Know If You Have One?" Bussines Strategy Review Summer 15, no. 2 (n.d.): 5-12.

David, Fred R. Manajemen Strategi. Jakarta: Salemba Empat, 2009.

J. H. Makawimbang. Supervisi Dan Peningkatan Mutu Pendidikan. Bandung: Alfabeta, 2011.

M. Abdullah. "Manajemen Mutu Pendidikan Sekolah." Jurnal Penelitian Pendidikan 17, no. 03 (n.d.): 190.

Maarif, Moh Ibnul, Ni Ketut Arismayanti, Agus Muriawan Putra, Jl R Goris, and No Denpasar. "Strategi Perencanaan Manajemen Sumber Daya Manusia Di Hotel the Patra Resort and Villas Bali Kabupaten Badung Bali." Kepariwisataan Dan Hospitalitas 3, no. 1 (2019): 211-225.

Mubarak, Faisal. "Faktor Dan Indikator Mutu Pendidikan Islam." Management of Education 1, no. 1 (2004): 10-18.

Nur Zazin. Gerakan Menata Mutu Pendidikan: Teori Dan Aplikasi. Yogyakarta: Ar-Ruzz Media, 2011.

Porter. Strategi Bersaing (Competitive Strategy): Teknik Menganalisis Industri Dan Pesaing. Tangerang: Karisma Pyblishing Group, 2007.

Sadikin, Ali, and Afreni Hamidah. "Pembelajaran Daring Di Tengah Wabah Covid-19." Biodik 6, no. 2 (2020): 109-119.

Saleh, Ahmad Muzawir. "Problematika Kebijakan Pendidikan Di Tengah Pandemi Dan Dampaknya Terhadap Proses Pembelajaran Di Indonesia" (n.d.).

Solehan. "Strategi Peningkatan Mutu Pendidikan Di Madrasah Aliah Negeri Muara Enim." Raden Fattah 14 (2014): 1-15.

Stephen J. Bagnato. Intervention, Authentics Assessment For Early Childhood. New York, 2007.

Sudrajat, Cucu Jajat, Mubiar Agustin, Leli Kurniati, and Dede Karsa. "Jurnal Obsesi : 
Jurnal Pendidikan Anak Usia Dini Strategi Kepala TK Dalam Meningkatkan Mutu Pendidikan Pada Masa Pandemi Covid 19 Abstrak" 5, no. 1 (2021): 508-520.

Suhendar, Soedjarwo, Ismet Basuki. "Analisis Pengaruh Kepemimpinan Kyai, Budaya Pesantren, Dan Motivasi Kerja Guru Terhadap Mutu Pendidikan Pesantren Di Provinsi Banten" 34 (2017): 161-172.

Supriadi, Oding. "Pengaruh Gaya Kepemimpinan Dan Kualitas Layanan Terhadap Mutu Pendidikan Di Kabupaten Pandeglang Provinsi Banten.” Tabularasa PPS UNIMED 6, no. 2 (2009): 98-111.

Susanto, Budi. "The Influence Of Headmaster Leadership, School Climate And Teacher Competence Toward Education Quality In Mts Jeneponto Regency" 1, no. 2 (2018): 23-39. 